\title{
Cervicomedullary Junction Ependymoma Associated with NF2: A Case Report and Literature Review
}

\section{Ependimoma da junção cervicobulbar associado a neurofibromatose tipo II: relato de caso e revisão de literatura}

\author{
Otávio T. da Silva ${ }^{1}$ \\ ${ }^{1}$ Departament of Neurology, Neurosurgical division, Universidade \\ Estadual de Campinas (Unicamp), Campinas-SP, Brazil \\ Arq Bras Neurocir 2017;36:141.
}

Dear Dr. Eberval Gadelha,

I am grateful for the publication of our article Cervicomedullary Junction Ependymoma Associated with NF2: a Case Report and Literature Review (doi: 10.1055/s-0036-1597574), in the last issue of Brazilian Neurosurgery, number 1, volume 36, 2017.

However, I would like to express an acknowledgement regarding Figure number 2, as it was the work of Dr. Roger Neves Mathias, kindly given to Dr. Helder Tedeschi as a contribution to the referred study and to academic production as a whole. On behalf of all authors, I express our gratitude for the images, in particular the one used on the issue cover.

Thanks,

\begin{abstract}
Address for correspondence Otávio T. da Silva, MD, Departamento Neurologia, Universidade Estadual de Campinas, Rua Tessália Vieira de Camargo, 126, Cidade Universitária, 13083-887 - Campinas, SP - Brasil (e-mail: turolo@gmail.com).
\end{abstract}

Prezado Dr. Eberval Gadelha,

Agradeço pela publicação de nosso artigo Ependimoma da junção cervicobulbar associado a neurofibromatose tipo II: relato de caso e revisão de literatura (doi: 10.1055/s-0036-1597574), na última edição da Arquivos Brasileiros de Neurocirurgia, número 1, volume 36, 2017.

Entretanto, gostaria de fazer uma retratação referente à Figura número 2, feita por Dr. Roger Neves Mathias, e gentilmente cedida ao Dr. Helder Tedeschi, como contribuição para o referido estudo, e para a produção acadêmica em geral. Em nome dos autores, agradeço pela imagem, particularmente a usada na capa da edição.

Grato. received

March 24, 2017

accepted

March 27, 2017

published online

May 24, 2017
DOI https://doi.org/

10.1055/s-0037-1603555. ISSN 0103-5355.
Copyright $(2017$ by Thieme Revinter Publicações Ltda, Rio de Janeiro, Brazil 